\title{
Overeducation: A Growing Phenomenon Among Ghanaian Teachers at the Pre-Tertiary Level? The Empirical Evidence
}

Isaac Addai

Faculty of Business Education,
University of Education, Winneba,
Ghana.
Email: iaddai@uew.edu.gh
Tel: +233205434821
Licensed:
This work is licensed under a Creative
Commons Attribution 4.0 License.

Keywords:

Overeducation

Phenomenon

Higher qualification

Masters degree

Diploma

Upskilling

Outskilling

Ghana.

Received: 3 June 2020

Revised: 6 July 2020

Accepted: 22 July 2020

Published: 7 August 2020

\begin{abstract}
This paper purposes to examine the phenomenon of overeducation which prevails in Ghana among the pre-tertiary teachers notably at the public (managed using the tax-payers money) Junior High School (JHS) where some public JHS teachers possess Masters' degree in a sector where a Diploma qualification is required to teach. Using the Cramer's V statistical modelling, findings indicate that the issue of the public Kumasi JHS Teachers possessing higher qualification of Masters degree could not be describe as a phenomenon of overeducation, but could best be described as outskilling, which denotes employees undertaking or acquiring skills training and higher qualifications with the intention that the employees will eventually leave the establishment and take those skills elsewhere. From a policy point of view, the Ghana Education Service (the employer) must review its employment policy to recognising and appreciating in terms of compensation and promotion the Public JHS teachers possessing the Masters degree to attenuate the phenomenon of outskilling, and turn it rather into upskilling, which is equipping workers with the tools and education needed for job within the same establishment.
\end{abstract}

Funding: This study received financial support in the form of Book and Research Allowance from the University of Education, Winneba.

Competing Interests: The author declares that there are no conflicts of interests regarding the publication of this paper.

\section{Introduction}

There has been a steady increase in the attainment of higher educational qualifications among the pretertiary public teachers notably at the Junior High School (JHS) level where some JHS teachers possesses Masters' degree in a sector where a Diploma qualification is required to teach which have the semblance of what is referred to in economic-sociology as overeducation. The phenomenon of overeducation was first brought to the attention of researchers in 1976 following the seminal paper by Freeman in his study of the US graduate labour market. Research interest on the phenomenon had increased since by focussing on assessing the implications of the continued rapid qualifications expansion in educational participation rates that has become a key feature of labour market in most economies (McGuinness, 2006). Overeducation typifies situations where highly qualified persons work at positions not requiring such higher qualifications and where there is a long-drawn persistence of the phenomenon, there is a signal for the economy that the labour market functions incorrectly. Overeducation has been extensively studied in economics and sociology (Borgna, Solga, \& Protsch, 2019). In Ghana, the socio-economic reality has been situations where some public JHS teachers have higher educational qualifications of Master degrees above the Diploma certificates which are required by the Ghana Education Service (GES) leading to excessive education (Budría \& Moro-Egido, 2009) another term for overeducation. This could be explained by the reason that many Ghanaians are receiving higher education leading to a corresponding increase in the number of students graduating from the universities in recent times in Ghana. For the 2016/2017 academic year for which data from the National Council for Tertiary Education (NCTE) exists in Ghana, student enrolment in the nine (9) public funded universities was 167,736 an increase of $7.94 \%$ compared with the 2015/2016 academic year student enrolment of 155,402 . Both the publicand private universities enrol students into sandwich, distance, evening, weekend programmes. For the 2016/2017 academic year, 80,119 students were enrolled in distance education programmes showing an increase of $62.64 \%$ in the distance programmes as compared to 49,261 students enrolled in the previous 
academic year. In the 2016/2017 academic year, 66,022 students were enrolled in the private tertiary institutions in Ghana. Public and private universities Master's Degree programmes students enrolment was 20,270 and 3,228 respectively. Of the total enrolment for postgraduate programmes, about $86.95 \%$ of the students were enrolled in Master's Degree programmes, National Council for Tertiary Education Statistical Report on Tertiary Education (2017).

The phenomenon of overeducation is very complex and some researchers have attempted to conceptualize and explain the problem within the framework of semi-formal socio-economic models. According to Spence (1973) job-screening model, the labour market is characterised by imperfect information, and education is used as a signal to identify more able and motivated individuals or more productive ones to employers. In order to acquire more of the signal, individuals will invest more in education, hoping that an additional amount of educational qualification suffices to distinguish them from others. Thus there is a tendency for the level of educational attainment of the labour force to rise relative to what is required of jobs, if job requirements do not change.

The private rate of return from educational investment can stay high and provide continuing incentives for investment in education. Thurow (1975) job competition theory predicts that an excess supply of graduates on the labour market causes persisting over-education of graduates whereas lower educated persons become unemployed. The privileging of graduates being employed has its origins in lower training costs for employers. He considers two queues: a job queue and a person queue. Each job in the job queue has its own skill requirements, productivity characteristics and pay scale. Individuals competing for jobs also form a queue, their relative position in the queue being determined by a set of characteristics such as education and experience that suggest to the employer the cost of training them and the skills necessary to perform a given job. The higher a person is in the person queue, the less is the cost of training and the more likely the person will be to get a job at the head of the job queue. Thus in order to place themselves higher up in the person queue, individuals will invest in education hoping that an additional amount of education will enhance their chance of getting a good job relative to others. Again, there is a tendency for the educational attainment of individuals in the person queue to rise relative to job-skill requirements if the job structure remains relatively unchanged; and the private rates of return from educational investment can stay high to provide continuing incentives for investment in education. Since each job has fixed skill requirements and the job structure is not responsive to changes in the relative supply of different skill groups, underutilization of worker skills will persist. Both Spence's job-screening model and Thurow's job-competition model indicate that overeducation can be a persistent problem if the job structure is unresponsive to changes in the relative supplies of educated workers. Finally, there exist substantial private and social incentives to educational investment that support an excess supply of overeducated workers. Stigler (1961) search theory postulate that over-education may temporarily arise due to labour market frictions in the context of incomplete information and receiving more education diminishes the incomplete information and the market friction enabling the individual gain employment in the short term. Overeducation is connected with structural mismatches on the labour market and is the result of the discrepancies between the job offers and the educational structure of workers. This also means a situation where there is no conformity between the existing professional structure and market needs and the structure of graduates leaving various higher education institutions of different profiles (Wronowska, 2017). Overeducation is potentially costly to the economy, where national welfare is potentially lower than would be the case if the skills of all overeducated workers were fully utilised within the economy and in addition, it may be that tax revenues are also being wasted on equipping individuals with non-productive education (McGuinness, 2006). Overeducation is a form of resource underutilisation, which may have implications for the individual, firm and the economy. It can also be seen as a form of underemployment, hence contributing to the extent of labour market slack. At the firm level, there is some evidence to suggest that overeducation is associated with lower productivity (McGuinness, 2006); (Green \& Henseke, 2016). Green and Henseke (2016) find a similar negative relationship at the industry level, for a large sample of Organisation for Economic Co-operation and Development (OECD) countries.

Overeducation of public JHS teachers in Ghana may thus result in reduced work effort, increased production cost and consequently lower productivity, implying a possible negative relationship between education and productivity. Could the phenomenon of overeducation in the pre-tertiary educational front be accountable for the various industrial strikes and agitation exhibited by the various teacher unions by the Ghana National Association of Teachers (GNAT), National Association of Graduate Teachers (NAGRAT) and The Concerned Teachers of Ghana? If this relationship exists, it will have important implications for both private and public policies. Individuals may have to reconsider their investment in education, the government will have to re-examine its policy regarding public subsidy to education and universities may have to redesign production to deal with the problems of overeducation. Considering these frameworks of semi-formal socioeconomic models espoused to explain the phenomenon of overeducation in developed economies the question of interest to this paper is, can the phenomenon of overeducation be explained by these socio-economic models in a developing economy like Ghana? Unfortunately, there has been no empirical study on the phenomenon of over-education in Ghana to the best of the author's knowledge and this paper set-the pace to bridge the gap. 
The structure of the paper is now outlined. The next is the data section, followed by the empirical model and empirical variables and summary statistics sections respectively. The statistical methodology section is next, followed by the empirical results section which discusses the study findings, concludes and proffers suggestions for future research.

\section{Data}

A unique individual-level survey comprising 128 public JHS teachers teaching in the Ashanti regional Capital of Kumasi was conducted by the author. The survey was conducted in 2018. The key informant purposive sampling methodology alongside snowballing was adopted using respondents teaching at the public JHS in Kumasi who are holders of Masters' degree to generate extensive useable array of information from them.

\section{Empirical Model}

The empirical model estimated in this paper is guided by some theoretical considerations that characterised the public JHS educational sector market in Ghana. Hence, a very general model of a public JHS teacher in Kumasi attributes for this paper is expressed as follows:

PJHST2d=f(gender, linkdeg, age, age2, ljbinfutre, duration, mode, married).

Where PJHST2d is the attributes of the second-degree holder public JHS teacher in the Ashanti-regional capital of Kumasi, gender captures the sexual characteristic of the individual the public JHS teacher in the Ashanti-regional capital, linkdeg captures whether second-degree holder public JHS teacher in the Ashantiregional capital of Kumasi second-degree certificate is in the same area as his/her Bachelor degree, age is the age in years of second-degree holder public JHS teacher in the Ashanti-regional capital of Kumasi and age 2 is the quadratic term. The use of age here is designed to capture the role of labour force experience and the quadratic captures the effects of human capital depreciation, Pham and Reilly (2007). ljbinfutre captures whether the second-degree holder public JHS teacher in the Ashanti-regional capital of Kumasi pursued the second-degree programme as a qualification to be used to gain employment in the educational sector of the economy or otherwise, duration captures number of years the second-degree holder public JHS teacher in the Ashanti-regional capital of Kumasi used in acquiring his/her second degree, mode captures whether seconddegree holder public JHS teacher in the Ashanti-regional capital of Kumasi obtained his her second-degree on full-time, distance, weekend, evening or distance mode, married captures the marital status of the seconddegree holder public JHS teacher in the Ashanti-regional capital of Kumasi.

The expectations is that:

a age/OPJHST2d $<0$.

The partial derivative of age of the respondents is negative, implying that considering respondents age, they pursued the higher qualification not to cling on to employment in the educational sector.

Table-1. Description and summary statistics of variables used.

\begin{tabular}{|c|c|c|c|}
\hline Variable & Description & Mean & Standard Deviation \\
\hline gender & $\begin{array}{l}\text { dummy }=1 \text { if JHS Teacher is male; }=0 \text { if } \\
\text { female. }\end{array}$ & & \\
\hline linkdeg & $\begin{array}{l}\text { dummy }=1 \text { if JHS Teacher 's Masters degree } \\
\text { is in the same field as Bachelor's degree; = O } \\
\text { otherwise }\end{array}$ & 0.0703125 & 0.2566776 \\
\hline age & $\begin{array}{l}\text { The age of the JHS Teacher expressed in } \\
\text { years }\end{array}$ & 36.25 & 4.097243 \\
\hline age2 & age squared & 1330.719 & 297.1442 \\
\hline ljbinfutre & $\begin{array}{l}\text { dummy }=1 \text { if JHS Teacher possess Masters } \\
\text { degree as an added advantage to cling unto } \\
\text { employment in the education sector; = } 0 \\
\text { otherwise. }\end{array}$ & 0.0390625 & 0.194505 \\
\hline duration & $\begin{array}{l}\text { number of years the respondent used in } \\
\text { acquiring his/her second degree }\end{array}$ & 3.179688 & 0.3854355 \\
\hline mode & $\begin{array}{l}\text { dummy if the respondent obtained his her } \\
\text { second-degree }=1 \text { if full-time mode, }=2 \text { if } \\
\text { distance mode, }=3 \text { if weekend mode, }=4 \text { if } \\
\text { evening mode }\end{array}$ & 1 & $\mathrm{O}$ \\
\hline married & $\begin{array}{l}\text { Dummy }=1 \text { if the respondent is married; }=0 \\
\text { if otherwise. }\end{array}$ & 0.6953125 & 0.4620835 \\
\hline Observations & 128 & & \\
\hline
\end{tabular}




\section{Empirical Variables and Summary Statistics}

A variety of explanatory variables used to investigate whether the public JHS teachers in the Ashanti regional Capital of Kumasi holding the second-degree are overeducated at the Kumasi JHS sector or not and the various summary statistics are now described in turn in Table 1.

The mean age of the respondent public JHS teachers in Kumasi was 36 years and it took an average of 3 years 2 months to complete a Master degree programme meant for two years. The average Masters degree was acquired though the distance study mode.

\section{Statistical Methodology}

The paper examines the association between two nominal variables. It examines the age of a respondent and whether his/her current qualification is purposely meant for the current job or is a form of 'insurance' for a different job. To test for the association between nominal level variables, the Cramer's V statistical test is applied.

The Cramer's V test is administered as:

$\mathrm{V}=\sqrt{\frac{\chi^{2}}{(N)(\min r-1, c-1)}}$

Where $\chi^{2}=\sum \frac{\left(f_{0}-f_{e}\right)^{2}}{f e}$

and $\chi^{2}$ is the Chi-square distribution and:

$f_{e}$ is the expected frequency for each cell.

$f_{0}$ is the observed (actual) frequency for each cell.

$r=$ number of rows.

$c=$ number of column.

\section{Empirical Results}

Table-2. Cramer's V Estimates of Association between Age of Public JHS Teaching Respondents and Whether $2^{\text {nd }}$ Degree Acquired is Because of their Current Teaching Job.

\begin{tabular}{|c|c|c|c|c|}
\hline $\begin{array}{r}= \\
\text { respondent } \\
\text { 's age }\end{array}$ & $\begin{array}{ll}1 \\
1 \\
1 \\
1 \\
1\end{array}$ & $\begin{array}{c}=1 \text { if } 2 \text { nd degre } \\
\text { ursued was meant } \\
\text { present job, } \\
\text { otherwise } \\
0\end{array}$ & $\begin{array}{l}\text { ee } \\
t \text { for } \\
0\end{array}$ & Total \\
\hline 29 & I & 3 & 01 & 3 \\
\hline 30 & I & 9 & $0 \quad 1$ & 9 \\
\hline 31 & I & 7 & 1 | & 8 \\
\hline 32 & I & 7 & 01 & 7 \\
\hline 33 & 1 & 18 & $0 \quad 1$ & 18 \\
\hline 34 & I & 7 & $0 \quad 1$ & 7 \\
\hline 36 & I & 6 & 01 & 6 \\
\hline 37 & I & 18 & 1 | & 19 \\
\hline 38 & i & 16 & 0 I & 16 \\
\hline 39 & 1 & 2 & 01 & 2 \\
\hline 40 & 1 & 1 & 01 & 1 \\
\hline 41 & 1 & 11 & 21 & 13 \\
\hline 42 & I & 16 & 1 I & 17 \\
\hline 43 & I & 1 & 01 & 1 \\
\hline 44 & I & 1 & $0 \quad 1$ & 1 \\
\hline Total & I & $\begin{array}{c}123 \\
\text { Cramér's v = }\end{array}$ & $\begin{array}{c}5 \quad \mid \\
0.2694\end{array}$ & 128 \\
\hline
\end{tabular}

The respondents age range from 29 years to 44 years. 96 percent (123) of the respondents' possession of the Masters degree was not meant for their present teaching job at the JHS, while 4 percent 5 respondents responded in the affirmative. To prove further, the Cramer's V test of association is conducted. The Cramer's $\mathrm{V}$ estimate of 0.27 is obtained. The estimate indicates a weak association between the age of respondent Teachers in the public Kumasi JHS sector, and the Masters degree qualification they possessed are not meant for their current jobs. The paper posits therefore that, the issue of some public Kumasi JHS Teachers 
possessing higher qualification of Masters degree than the Diploma required for teaching could not be describe as a phenomenon of overeducation, but could best be described as outskilling. Outskilling implies employees undertaking or acquiring skills training and higher qualifications with the intention that the workers will eventually leave the establishment and take those skills elsewhere. That is, the higher skills and qualification the public Kumasi JHS teachers currently possessed are not meant for the productivity of their current jobs. From a policy point of view, the GES must review its employment policy guidelines to recognise and appreciate in terms of compensation and remuneration those of the Public JHS teachers possessing the Masters degree to attenuate the phenomenon of outskilling and turn it into upskilling, which is equipping workers with the tools and education needed for job within the same establishment. Majority of the respondents obtained their masters degree by distance mode. Further research to investigate whether acquiring Masters degree through distance education offers the same skills and competencies to students as compared to those who pursued their Masters degree as residential students on a university campus in Ghana remains an agenda for future research.

\section{References}

Borgna, C., Solga, H., \& Protsch, P. (2019). Overeducation, labour market dynamics, and economic downturn in Europe. European Sociological Review, 35(1), 116-132. Available at: DOI: 10.1093/esr/jcy046.

Budría, S., \& Moro-Egido, A. I. (2009). The overeducation phenomenon in Europe. International Journal of Sociology, 67(2), 329-345. Available at: http://dx.doi.org/10.3989/ris.2008.02.01.

Green, F., \& Henseke, G. (2016). Should governments of OECD countries worry about graduate underemployment? Oxford Review of Economic Policy, 32(4), $514-537$.

McGuinness, S. (2006). Overeducation in the labour market. Journal of Economic Surveys, 20, 387-418. Available at: http://dx.doi.org/10.1111/j.0950-0804.2006.00284.x.

National Council for Tertiary Education Statistical Report on Tertiary Education. (2017). Accra, Ghana: National Council for Tertiary Education Statistical Report on Tertiary Education.

Pham, T.-H., \& Reilly, B. (2007). The gender pay gap in Vietnam, 1993-2002: A quantile regression approach. Journal of Asian Economics, 18(5), 775-808. Available at: https://doi.org/10.1016/j.asieco.2007.04.001.

Spence, M. (1973). Job market signalling. Quarterly Journal of Economics, 87(3), 355-374.

Stigler, G. J. (1961). The economics of information. Journal of Political Economy, 69(3), 213-225.

Thurow, L. C. (1975). Generating inequality. New York: Basic Books.

Wronowska, G. (2017). Overeducation in the labour market. Paper presented at the 9th International Conference on Applied Economics Contemporary Issues in Economy, 22-23 June Poland. 